\title{
Effects of long-term treatment with timolol on lacrimal gland function
}

\author{
R. L. COAKES, ${ }^{1}$ I. A. MACKIE, ${ }^{2}$ AND D. V. SEAL ${ }^{3}$ \\ From 'Moorfields Eye Hospital, High Holborn, London WC1; the ${ }^{2}$ Department of Ophthalmology, \\ St George's Hospital, Blackshaw Road, London SW7; and the ${ }^{3}$ Public Health Laboratory, B Level, \\ South Block, General Hospital, Tremona Road, Southampton SO9 $4 X Y$
}

SUMMARY Thirty-two patients with raised intraocular pressure were treated for 1 year with topical timolol $0.5 \%$ twice daily. There was satisfactory pressure reduction on this drug alone in 25 patients. The tear flow (modified Schirmer I test) was measured, and the tear lysozyme concentration was assayed before, and at 3,6, and 12 months after beginning treatment. No subjective symptoms occurred and no side effects were recorded. The tear flow and tear lysozyme concentration were not significantly reduced.

Timolol maleate (Timoptol) a $\beta_{1}$ and $\beta_{2}$ adrenergic receptor blocking drug, is widely used in the treatment of glaucoma. ${ }^{1}$ Patient tolerance is good, largely because of the absence of local side effects. ${ }^{2}$ Systemic absorption of the drug may, however, give rise to adverse cardiovascular, respiratory, and central nervous system reactions in susceptible patients. ${ }^{3}$ Few adverse ocular reactions to timolol have so far been reported, the more serious being sporadic reports of superficial punctate keratopathy and corneal anaesthesia. ${ }^{34}$ No prospective study has yet been carried out. The apparent lack of local anaesthetic activity (membrane-stabilising effect) with timolol compared with other beta-blocking drugs is one reason for its introduction for topical use. ${ }^{5}$

Severe adverse ocular reactions have been encountered in the past with the $\beta_{1}$-selective blocking drug practolol..$^{6}$ Patients who developed an oculomucocutaneous syndrome following its systemic administration were found to have decreased tear flow as well as a reduced concentration of tear lysozyme and $\operatorname{IgA}$, indicating severe impairment of lacrimal gland function. ${ }^{6} \mathrm{~A}$ significantly reduced concentration of tear lysozyme was also found in patients who were taking practolol but whose eyes were clinically normal.? It was therefore considered important that a critical prospective study be made of the effect of the long-term administration of timolol on lacrimal gland function. This paper reports our

Correspondence to $\mathrm{Mr} \mathrm{R}$. L. Coakes FRCS, Moorfields Eye Hospital, High Holborn, London WC1V 7AN. findings, which contradict those of a recently published study that suggested timolol adversely affected lacrimal gland function. ${ }^{8}$

\section{Patients and methods}

Thirty-two patients of both sexes with newly diagnosed primary open-angle glaucoma (POAG) (23 patients, 44 eyes) or ocular hypertension $(\mathrm{OH})$ requiring treatment (9 patients, 17 eyes) were included in the study. Their mean age was 61 years, range 20 to 79 years. All satisfied the following admission criteria: (1) no systemic disease contraindicating the use of beta-blocking drugs; (2) no external eye disease; (3) no existing topical ocular medication; (4) no concurrent treatment with systemic beta-blocking drugs or antibiotics.

Informed consent was obtained, and treatment was started with topical timolol $0.5 \%$ twice daily.

Slit-lamp examination of the external eye and measurement of tear flow and tear lysozyme concentration were carried out before beginning treatment with timolol and repeated after 3,6 , and 12 months. Assessment of intraocular pressure (IOP) control by applanation tonometry was carried out as frequently as deemed necessary and visual field examination after 6 and 12 months. An intraocular pressure of 21 $\mathrm{mmHg}$ or less (or minimal fall of $5 \mathrm{mmHg}$ from the baseline IOP if $25 \mathrm{mmHg}$ or less) was accepted as evidence of adequate control in those patients with primary open-angle glaucoma. For the ocular hypertensive patients an intraocular pressure of $24 \mathrm{mmHg}$ 
or less (or a minimal fall of $5 \mathrm{mmHg}$ from the baseline IOP if $28 \mathrm{mmHg}$ or less) was accepted.

Tear flow was measured with Schirmer's strips in the unanaesthetised open eye. If wetting did not occur within 2 minutes the strip was removed and placed in another area of the lower fornix, and time counting was started again. This is a modification of the Schirmer I test. ${ }^{9}$ The length of wetted strip was recorded after 5 minutes. The maximum length was considered to be $30 \mathrm{~mm}$.

Estimation of tear lysozyme concentration was carried out according to the method of Seal et al., ${ }^{10}$ but the results were expressed in units per microlitre. Hen egg lysozyme standard was used, which had an activity of 24300 units per milligram. Tear samples were collected 5 minutes prior to the Schirmer's test on $5 \mathrm{~mm}$ filter paper discs placed in the lower fornix. The discs were weighed in their bottles on a portable Cahn electronic balance before and after collection to give the weight, and hence volume, of the tear fluid collected. A known volume of eluting fluid was then added to the disc in its bottle prior to transport to the assay laboratory, where it was stored at $-20^{\circ} \mathrm{C}$.

\section{Results}

All 32 patients tolerated timolol well and no subjective side effects were recorded. No abnormality of the tear film, conjunctiva, or cornea was detected on slit-lamp examination in any patient during the 12month study. Additional medication to control the IOP was required in 7 patients ( 13 eyes). Six patients (11 eyes) were adequately controlled by the addition of pilocarpine alone and were kept in the study. One patient required drainage surgery and was removed from the study after 5 months. One female patient, aged 77, with primary open-angle glaucoma, died 11 months after starting treatment with timolol.

The results of the modified Schirmer I tests and tear lysozyme estimations are given in Table 1 . There was no significant difference between the mean values of the Schirmer I tests after 3, 6, and 12 months of

Table 1 Results of mean values of Schirmer tests and tear lysozyme concentrations

\begin{tabular}{|c|c|c|c|c|c|}
\hline \multirow[t]{2}{*}{ Test } & \multirow{2}{*}{\multicolumn{2}{|c|}{$\begin{array}{l}\text { Patients before } \\
\text { treatment }\end{array}$}} & \multicolumn{3}{|c|}{ Patients using $0.5 \%$ timolol drops } \\
\hline & & & $\begin{array}{l}\text { After } \\
3 \text { months }\end{array}$ & $\begin{array}{l}\text { After } \\
6 \text { months }\end{array}$ & $\begin{array}{l}\text { After } \\
12 \text { months }\end{array}$ \\
\hline $\begin{array}{l}\text { Schirmer I } \\
\text { (modified) }\end{array}$ & $\begin{array}{l}\text { Right } \\
\text { Left }\end{array}$ & $\begin{array}{l}23(8) \\
21(9)\end{array}$ & $\begin{array}{l}22(9) \\
20(8)\end{array}$ & $\begin{array}{l}22(9) \\
22(9)\end{array}$ & $\begin{array}{l}23(9) \\
23(9)\end{array}$ \\
\hline $\begin{array}{l}\text { Tear lysozyme } \\
\text { concentration } \\
\text { (units/ } \mu \mathrm{l} \text { ) }\end{array}$ & $\begin{array}{l}\text { Right } \\
\text { Left }\end{array}$ & $\begin{array}{l}126(38) \\
127(40)\end{array}$ & $\begin{array}{l}129(50) \\
121(47)\end{array}$ & $\begin{array}{l}144(39) \\
146(47)\end{array}$ & $\begin{array}{l}107(25) \\
109(24)\end{array}$ \\
\hline
\end{tabular}

Standard deviation shown in parentheses.
Table 2 Mean intraocular pressure in eyes treated with timolol alone

\begin{tabular}{|c|c|c|c|c|c|c|}
\hline & \multicolumn{2}{|c|}{$\begin{array}{l}\text { Primary open-angle } \\
\text { glaucoma }\end{array}$} & \multicolumn{2}{|c|}{$\begin{array}{l}\text { Ocular } \\
\text { hypertension }\end{array}$} & \multicolumn{2}{|c|}{ All eyes } \\
\hline & $n$ & $\begin{array}{l}\text { IOP } \\
\mathrm{mmHg}\end{array}$ & $n$ & $\begin{array}{l}I O P \\
m m H g\end{array}$ & $n$ & $\begin{array}{l}I O P \\
m m H g\end{array}$ \\
\hline Pretreatment & 44 & $28 \cdot 7(6 \cdot 2)$ & 17 & $29.5(3.4)$ & 61 & $28.9(5.6)$ \\
\hline At 2 weeks & 44 & $17 \cdot 8(3 \cdot 4)$ & 17 & $20 \cdot 5(2 \cdot 9)$ & 61 & $18.6(3.5)$ \\
\hline At 3 months & 39 & $18 \cdot 3(3.1)$ & 17 & $21 \cdot 1(2 \cdot 5)$ & 56 & $19 \cdot 1(3 \cdot 2)$ \\
\hline At 6 months & 37 & $17 \cdot 6(2 \cdot 7)$ & 17 & $20 \cdot 4(2 \cdot 2)$ & 54 & $18.5(2.8)$ \\
\hline At 12 months & 31 & $17 \cdot 0(2 \cdot 6)$ & 17 & $21 \cdot 2(4 \cdot 5)$ & 48 & $18 \cdot 3(3.6)$ \\
\hline
\end{tabular}

$n=$ Number of eyes. Standard deviation shown in parentheses.

topical timolol therapy when compared with the values before treatment was started. There was also no significant difference between the mean values of the tear lysozyme concentrations, at similar periods after starting timolol therapy, when compared with the pretreatment values, although the mean concentrations fluctuated within the limits of the normal range at 6 and 12 months.

The results of pressure lowering by timolol are given in Table 2. Adequate control of IOP by timolol alone was achieved in $70 \%$ (31 out of 44 ) of eyes with POAG over the 12 month period. Acceptable IOP lowering was achieved in all eyes with $\mathrm{OH}$ until the end of the 12 month period, when the IOP was found to be above $24 \mathrm{mmHg}$ in 3 eyes.

\section{Discussion}

The lacrimal gland has a dual innervationsympathetic and parasympathetic. The sympathetic nerve supply is from the superior cervical ganglion through the carotid plexus, and within the lacrimal gland there is a fine network of adrenergic fibres running between the secretory acini. ${ }^{11}$ The role of the sympathetic is not fully understood, but Whitwell found that the injection of adrenaline into the gland stimulated secretion in the denervated human lacrimal gland. ${ }^{12}$

In a recent study ${ }^{13}$ it has been shown that the sympathetic plays a dominant role in the control of lacrimal protein secretion. Beta-receptors have been demonstrated on the acinar cells of the rabbit lacrimal gland, ${ }^{14}$ and blockage of these receptors has been shown to partially inhibit protein secretion in response to adrenergic stimulation. ${ }^{13}$ Antibacterial proteins present in tear fluid include IgA, IgG, complement, lysozyme, lactoferrin, and caeruloplasmin. ${ }^{15} 16$

We have found no significant reduction in tear flow or in tear lysozyme concentration in our patients on topical timolol $0.5 \%$ twice daily. These findings contradict those of Bonomi et al., ${ }^{8}$ who recorded a 
significant reduction $(p<0.01)$ in tear flow and lysozyme concentration in 30 patients with openangle glaucoma at 7 and 45 days after treatment with topical timolol $0.25 \%$ twice daily. They did not, however, find a reduction in IgA which might be expected if the lysozyme concentration was reduced. ${ }^{6}$ We found timolol was well tolerated in our patients and associated with no subjective symptoms. The therapeutic effectiveness of timolol in lowering IOP was also confirmed.

We are grateful to Merck Sharp and Dohme Ltd for providing equipment for this study and thank Dr B. Faroogi for valuable technical assistance.

\section{References}

1 Editorial. Beta blockers for glaucoma. Lancet 1979; i: 1064-5.

2 Zimmerman TJ, Kass MA, Yablonski ME, Becker B. Timolol maleate-efficacy and safety. Arch Ophthalmol 1979; 97: 656-8.

3 McMahon CD, Schaffer RN, Dunbar Hoskins H, Hetherington J. Adverse effects experienced by patients taking timolol. Am J Ophthalmol 1979; 88: 736-8.

4 van Buskirk EM. Corneal anaesthesia after timolol maleate therapy. Am J Ophthalmol 1979; 88: 739-43.

5 Heel RC, Brogden RN, Speight TM, Avery GS. Timolol: a review of its therapeutic efficacy in the topical treatment of glaucoma. Drugs 1979; 17: 38-45.

6 Wright P. Untoward effects associated with practolol administration: oculomucocutaneous syndrome. BrMed J 1975; i: 595-8.

7 Mackie IA, Seal DV, Pescod JM. Beta-adrenergic receptor blocking drugs: tear lysozyme and immunological screening for adverse reaction. Br J Ophthalmol 1977; 61: 354-9.

8 Bonomi L, Zavarise G, Noya E, Michieletto S. Effects of timolol maleate on tear flow in human eyes. Albrecht von Graefes Arch Klin Ophthalmol 1980; 213: 19-22.

9 Mackie IA, Seal DV. The questionably dry eye. Br J Ophthalmol 1981; 65: 2-9.

10 Seal DV, Mackie IA, Coakes RL, Farooqi B. Quantitative tear lysozyme assay: a new technique for transporting specimens. $\mathrm{BrJ}$ Ophthalmol 1980; 64: 700-4.

11 Ehinger B. Adrenergic nerves to the eye and to related structures in man and in the cynomolgus monkey (Macaca irus). Invest Ophthalmol Visual Sci 1966; 5: 42-52.

12 Whitwell J. Role of the sympathetic in lachrymal secretion. Br J Ophthalmol 1961; 45: 439-45.

13 Bromberg BB. Autonomic control of lachrymal protein secretion. Invest Ophthalmol Visual Sci 1981; 20: 110-6.

14 Dikstein S. Drugs and ocular tissues. Second Meeting of International Society for Eye Research 1976. London: Karger, 1977: 42-6.

15 Sapse AT, Bonavida B, Stone W, Sercaz EE. Proteins in human tears. I. Immunoelectrophoretic patterns. Arch Ophthalmol 1969; 81: 815-9.

16 Yamamoto GK, Allansmith MR. Complement in tears from normal humans. Am J Ophthalmol 1979; 88: 758-63. 